\title{
Comparison Between the Potential of Tempe Flour Made from Germinated and Nongerminated Soybeans in Preventing Diabetes Mellitus
}

\author{
Made Astawan $^{1 *}$, Inas Suci Rahmawati ${ }^{1}$, Ananda Putri Cahyani ${ }^{1}$, Tutik Wresdiyati ${ }^{2}$, Sastia Prama Putri ${ }^{3}$, Eiichiro Fukusaki ${ }^{3}$ \\ ${ }^{1}$ Department of Food Science and Technology, Faculty of Agricultural Engineering and Technology, Bogor Agricultural University, \\ Bogor, Indonesia \\ ${ }^{2}$ Department of Anatomy, Physiology, and Pharmacology, Faculty of Veterinary Medicine, Bogor Agricultural University, Bogor, Indonesia \\ ${ }^{3}$ Laboratory of Bioresource Engineering, Department of Advanced Science and Biotechnology, Graduate School of Engineering, Osaka \\ University, Japan
}

\section{ARTICLE INFO}

Article history:

Received April 1, 2019

Received in revised form August 2, 2019

Accepted August 10, 2019

KEYWORDS:

diabetes,

tempe,

antioxidant,

isoflavones,

$\alpha$-amylase,

$\alpha$-glucosidase

\begin{abstract}
This study was aimed to compare the chemical characteristics of tempe flour made from nongerminated soybean (NST) and germinated soybean (GST), especially on their capacity in preventing diabetes mellitus (DM). Soybeans were germinated for 20 hours in the dark until $2.5-5.0 \mathrm{~mm}$ of the radicle emerged. The ungerminated soybeans and the germinated soybeans were then processed into tempe and tempe flour. The two types of tempe flour were subjected to proximate analysis, amino acid profiling, antioxidant capacity, total phenol content, isoflavone content, and $\alpha$-amylase and $\alpha$-glucosidase enzyme inhibition analyses. GST was superior in preventing DM in the protein content and antioxidant parameters, as these were significantly higher $(\mathrm{p}<0.05)$ than in NST. On the other hand, NST was superior in preventing diabetes in the isoflavon (daidzein, genistein, and total isoflavone) and $\alpha$-amylase inhibition $\mathrm{IC}_{50}$ parameters which were significantly better $(\mathbf{p}<0.05)$ than in GST. On the contrary, the diabetes-preventing parameters total phenols, $\alpha$-glucosidase inhibition $\mathrm{IC}_{50}$, and insulinotropic amino acids (arginine, alanine, phenilalanine, isoleucine, leucine, and lysine) were not different $(p>0.05)$. Therefore, GST and NST both have potential in preventing diabetes through different mechanisms.
\end{abstract}

\section{Introduction}

Diabetes mellitus is a metabolic disorder characterized by chronic hyperglycemia due to a defect in insulin production, insulin action, or both (American Diabetes Association 2010). Oxidative stress plays an important role in diabetes mellitus etiology and is responsible for damaging pancreatic $\beta$-cells. Therefore, controlling the blood glucose level, inhibiting oxidative stress (El-Kordy and Alshahrani 2015), and increasing body antioxidant defensive system (Shahidi et al. 2012) have been suggested to manage diabetes mellitus.

Plants high in antioxidants such as vitamin E, vitamin $C, \beta$-carotene, and polyphenols have been used as traditional medicine to treat diabetes in several regions. Antioxidants are compounds which actively bind reactive oxygen species (ROS) and protect

\footnotetext{
* Corresponding Author

E-mail Address: astawan@apps.ipb.ac.id
}

pancreatic $\beta$-cells from oxidative stress (Firdaus et al. 2010). In addition to the ROS-binding mechanism, antioxidants can act as antidiabetic agents due to their ability to inhibit carbohydrate absorption. Inhibition of carbohydrate absorption occurs as antioxidants are able to inhibit $\alpha$-glucosidase and $\alpha$-amylase activities, inhibit gluconeogenesis, stimulate pancreas activity, and increase insulin sensitivity (Shahidi et al. 2012).

Acarbose is commonly used as an $\alpha$-amylase and $\alpha$-glucosidase inhibitor in diabetes treatment. Acarbose reduces the complex carbohydrate digestion rate which later decreases glucose absorption in the small intestines. However, acarbose has several gastrointestinal side effects, including flatulence, abdominal discomfort, and diarrhea (Setter et al. 2006). Phenolic extracts generally have slightly weak $\alpha$-amylase inhibition but have a stronger ability in inhibiting $\alpha$-glucosidase that does not give rise to significant side effects (Adefegha and Oboh 2016). 
Bioactive compounds that show antidiabetic activities in legumes are isoflavones, an $\alpha$-amylase inhibitor, and an $\alpha$-glucosidase inhibitor (Gętek et al. 2014). A study regarding germination of soy demonstrated that it was able to increase the bioactive compounds (Puteri et al. 2018). During germination, the seeds undergo various biochemical and enzymatic reactions; therefore, increasing their nutritional value and digestibility compared to the seeds without germination process (Márton et al. 2010). Germination increases the amount of vitamin $\mathrm{E}$, total isoflavones, antioxidant capacity, calcium, phosphorus, iron, and zinc content in germinated soy tempe flour compared to nongerminated soy tempe flour (Astawan et al. 2016a). In addition to the potential of germination soybean as antidiabetic has been evidenced by the presence of insulinotropic amino acids that play role in increasing insulin secretion such as alanine, arginine, phenylalanine, isoleucine, leucine, and lysine (Kanetro and Astuti 2013).

Tempe, a fermented soybean by Rhizopus spp mold originally from Indonesia, is an excellent protein source with high nutritional quality (Astawan et al. $2016 b)$. Differences in the production process and unique fermentation condition in different regions result in varieties of tempe (Kadar et al. 2018). Tempe has higher nutritional values compared to soybeans because the fermentation process degrades carbohydrate, fat, and protein into their respective building blocks (Astawan et al. 2015). Aside from its increased digestibility, tempe contains higher aglycone isoflavones compared to soybeans (Sumi and Yatagai 2006). Fresh tempe is highly perishable and has a short shelf life. Processing tempe into flour is an alternative method to increase its shelf life (Astawan et al. 2017). This study was aimed to compare the characteristics of germinated soybean tempe flour (GST) and nongerminated soybean tempe flour (NST), especially the chemical compounds which act as antidiabetics.

\section{Materials and Methods}

\subsection{Sample Preparation}

The main ingredient used in this research was the local Grobogan variety soybean (Glycine max) collected from farmers in Grobogan, Central Java, Indonesia. The germination process was done by soaking the soybeans in water for 3 hours, then draining them, and incubating them for 20 hours in a dark condition. During the incubation process, the soybeans were sprayed with water every 4 hours to maintain their humidity (Puteri et al. 2018).

Tempe production was done according to Rumah Tempe Indonesia (Indonesian House of Tempe). Soybeans were soaked for 2-4 hours, boiled for 30 minutes, and soaked for 18-30 hours in clean water added with some of the boiled water used before. Through soaking, the $\mathrm{pH}$ would decrease (the target $\mathrm{pH}$ being 4.0-5.0). After that, the soybeans were ground, peeled, cleaned, rinsed with hot water, and drained at room temperature. After draining, the soybeans were inoculated with the commercial starter culture "RAPRIMA" produced by LIPI Bandung (2 grams per kilogram of dry soybeans) and then fermented for 48 hours. The first 24 hours was done at $30-34^{\circ} \mathrm{C}$, while the second 24 hours at room temperature (below $30^{\circ} \mathrm{C}$ ) (Astawan et al. 2017).

Tempe was further processed into flour according to the method by Astawan et al. (2015). Fresh tempe was sliced, steam blanched for 2 minutes, and then dried using an oven $(\mathrm{GmbH} 6072$ Dreieich, West Germany) at $60^{\circ} \mathrm{C}$ for 8 hours. Dried tempe was ground using a disc-mill and sifted using a 60 mesh sieve. The flour was stored in a tightly sealed container. Tempe flour was used for chemical analysis consisting of proximate analysis, crude fiber, amino acids profile, isoflavones, and vitamin $\mathrm{E}$ analyses.

Tempe flour was further extracted with ethanol according to the $\mathrm{Xu}$ and Chang (2007) method with modifications. Flour was extracted with ethanol/ water $(70: 30 \mathrm{v} / \mathrm{v})$ at a ratio of $1: 5(\mathrm{~b} / \mathrm{v})$, shaken with a stirrer at room temperature for 3 hours, extracted for additional 12 hours in a dark condition, filtered through Whatman Paper No. 1, and followed by centrifugation (Centrifuge 5810R Eppendorf, Hamburg, Germany) 300 x g for 10 minutes. Ethanol was removed by a rotary evaporator (Rotavapor R-210 Buchi Labortechnik AG, Flawil, Switzerland) at $45^{\circ} \mathrm{C}$. The extract was stored at $4^{\circ} \mathrm{C}$ in the dark until further analysis. This extract was used for antioxidant, total phenolics, and inhibition of $\alpha$-amylase and $\alpha$-glucosidase analyses.

\subsection{Chemical Component Analysis}

Moisture, ash, protein, fat, carbohydrate by difference, crude fiber, vitamin $\mathrm{E}$, total isoflavone, and amino acids profile were determined using methods described by the Association of Official 
Analytical Chemist (AOAC 2012). The total phenolics content was determined using the method described by Koh et al. (2012). A total of $1 \mathrm{ml}$ tempe flour extract was placed in a test tube and mixed with $5 \mathrm{ml}$ FolinCiocalteu reagent (1:1 with water). The mixture was allowed to stand at room temperature for 5 minutes. Then $4 \mathrm{ml}$ of sodium carbonate solution $(7.5 \% \mathrm{w} / \mathrm{v})$ was added and mixed thoroughly. The tubes were placed in a dark condition for 2 hours and the absorbance was measured at $765 \mathrm{~nm}$. Gallic acid (Sigma-Aldrich) was used as the standard and the amount of total phenolics content was calculated as a Gallic Acid Equivalent (GAE).

\subsection{Antioxidant Capacity Analysis}

The antioxidant capacity analysis was determined using method described by Hung and Nhi (2012). A total of $0.1 \mathrm{ml}$ tempe flour extract was mixed with 3.9 $\mathrm{ml}$ of $0.075 \mathrm{mM}$ DPPH (2-diphenyl-1-picrylhydrazyl) (Sigma-Aldrich) solution. The mixture was allowed to stand at room temperature in the dark for 30 minutes. The absorbance was measured at $517 \mathrm{~nm}$. Ascorbic acid (Sigma-Aldrich) was used as the standard and the antioxidant capacity was expressed as an AEAC (Ascorbic Acid Equivalent Antioxidant Capacity).

\subsection{Alpha-amylase Inhibition Assay}

The alpha-amylase inhibition assay was conducted using method described by Thalapaneni et al. (2008). A total of $125 \mu$ lempe flour extract was added to the same amount of sodium phosphate buffer $(\mathrm{pH}$ 6.9 with $0.006 \mathrm{M} \mathrm{NaCl}$ ) containing $1 \mathrm{U} / \mathrm{ml} \alpha$-amylase (from Aspergillus oryzae) solution (Sigma-Aldrich). The mixture was incubated at $37^{\circ} \mathrm{C}$ for 10 minutes. Then, $125 \mu \mathrm{l}$ of $1 \%$ corn soluble starch (SigmaAldrich) solution was added and the mixture was incubated again at $37^{\circ} \mathrm{C}$ for 10 minutes. The reaction was terminated by adding $250 \mu \mathrm{l}$ dinitrosalicylic acid (DNS) solution and incubated in a boiling water bath for 5 minutes. The reaction mixture was then diluted by adding $5 \mathrm{ml}$ of distilled water. The absorbance was measured at $540 \mathrm{~nm}$.

\subsection{Alpha-glucosidase Inhibition Assay}

The alpha-glucosidase inhibition assay was done using method described by Sancheti et al. (2009). A total of $10 \mu \mathrm{l}$ tempe flour extract was mixed with 50 $\mu \mathrm{l}$ of $0.1 \mathrm{~m}$ potassium phosphate buffer ( $\mathrm{pH} 7.0$ ), 25 $\mu l \rho$-nitrophenyl- $\alpha$-D-glucopyranoside (dissolved in $0.1 \mathrm{~m}$ potassium phosphate $\mathrm{pH} 7.0$ ), and $25 \mu$ l of 0.04 $\mathrm{U} / \mathrm{ml} \alpha$-glucosidase (from Saccharomyces cerevisiae) solution (Sigma-Aldrich). The mixture was incubated at $37^{\circ} \mathrm{C}$ for 30 minutes. The reaction was terminated by adding $100 \mu \mathrm{l}$ of $0.2 \mathrm{~m}$ sodium carbonate. The mixture was then diluted by adding $1 \mathrm{ml}$ of distilled water. The absorbance was measured at $405 \mathrm{~nm}$.

\section{Results}

Soybean germination before processing into tempe flour changed the content of several components analyzed. The result of the proximate analysis and crude fiber analysis are presented in Table 1 . The germination process increased moisture $(p<0.01)$, protein and crude fiber contents $(p<0.05)$ of the tempe flour yielded, while the carbohydrate content decreased $(p<0.01)$. Fat, and ash contents demonstrated no change.

As shown in Table 2, most amino acids did not change significantly and only a few suffered a decrease. The germination process significantly decreased the aspartic acid level $(p<0.01)$, followed by threonine, valine, and leucine $(\mathrm{p}<0.05)$. Among the essential amino acids, leucine was the highest in amount in both tempe flours, while the lowest in amount was methionine. In addition, the content of insulinotropic amino acids such as arginine, alanine, phenylalanine, isoleucine, and leucine tends to decline due to the germination process of soybeans.

Table 3 presents the result of the antioxidant analysis and the components which were expected to be involved in the antioxidant activity. The antioxidant capacity of GST was higher than NST $(\mathrm{p}<0.05)$. However, total isoflavones content in GST was decreased $(\mathrm{p}<0.01)$, while the total phenolics content did not show significant change.

Germination decreased the inhibition of $\alpha-$ amylase and $\alpha$-glucosidase $(\mathrm{p}<0.05)$ that shown by the increased of their $\mathrm{IC}_{50}$ value. The $\mathrm{IC}_{50}$ value of $\alpha$-amylase was significantly lower $(74.8 \mathrm{mg} / \mathrm{ml})$ in NST as compared to GST $(92.0 \mathrm{mg} / \mathrm{ml})$. The similar result was also observed in $\alpha$-glucosidase, where NST had $\mathrm{IC}_{50}$ value significantly lower $(85.3 \mathrm{mg} / \mathrm{ml})$ as compared to GST $(115.9 \mathrm{mg} / \mathrm{ml})$, as shown in Figure 1 .

\section{Discussion}

Various biochemical and enzymatic reactions occur during the germination process that breaks down macromolecules into their respective building blocks. Macromolecule breakdown increases the 
Table 1. Proximate analysis and crude fiber content of tempe flours

\begin{tabular}{lll}
\hline \multirow{2}{*}{ Parameter } & \multicolumn{2}{c}{ Tempe flour from } \\
\cline { 2 - 3 } & $\begin{array}{l}\text { Nongerminated } \\
\text { soybean }\end{array}$ & $\begin{array}{l}\text { Germinated } \\
\text { soybean }\end{array}$ \\
\hline Moisture (\% wb) & $3.92 \pm 0.82^{\mathrm{a}}$ & $5.98 \pm 1.03^{\mathrm{b}}$ \\
Ash $(\% \mathrm{db})$ & $2.08 \pm 0.05^{\mathrm{a}}$ & $1.89 \pm 0.11^{\mathrm{a}}$ \\
Fat $(\% \mathrm{db})$ & $25.94 \pm 1.35^{\mathrm{a}}$ & $25.65 \pm 0.99^{\mathrm{a}}$ \\
Protein $(\% \mathrm{db})$ & $50.69 \pm 0.53^{\mathrm{a}}$ & $52.98 \pm 0.55^{\mathrm{b}}$ \\
Cabohydrate $(\% \mathrm{db})$ & $17.36 \pm 1.70^{\mathrm{b}}$ & $13.50 \pm 2.46^{\mathrm{a}}$ \\
Crude fiber $(\% \mathrm{db})$ & $5.05 \pm 0.06^{\mathrm{a}}$ & $6.59 \pm 0.10^{\mathrm{b}}$ \\
\hline \multicolumn{2}{l}{ Different superscripts in the same row means statistically } \\
\multicolumn{2}{c}{ different $(\mathrm{p}<0.05)$}
\end{tabular}

Table 2. Amino acid profile of tempe flours

\begin{tabular}{lcc}
\hline \multirow{2}{*}{ Parameter $(\%, \mathrm{db})$} & \multicolumn{2}{c}{ Tempe flour from } \\
\cline { 2 - 3 } & $\begin{array}{l}\text { Nongerminated } \\
\text { soybeans }\end{array}$ & $\begin{array}{l}\text { Germinated } \\
\text { soybeans }\end{array}$ \\
\hline Aspartic acid & $6.14 \pm 0.06^{\mathrm{b}}$ & $5.64 \pm 0.05^{\mathrm{a}}$ \\
Glutamic acid & $10.17 \pm 0.23^{\mathrm{a}}$ & $9.49 \pm 0.09^{\mathrm{a}}$ \\
Serine & $2.76 \pm 0.03^{\mathrm{a}}$ & $2.48 \pm 0.15^{\mathrm{a}}$ \\
Histidine & $1.18 \pm 0.01^{\mathrm{a}}$ & $1.18 \pm 0.08^{\mathrm{a}}$ \\
Glycine & $1.93 \pm 0.03^{\mathrm{a}}$ & $1.97 \pm 0.06^{\mathrm{a}}$ \\
Threonine & $2.15 \pm 0.03^{\mathrm{b}}$ & $1.97 \pm 0.04^{\mathrm{a}}$ \\
Arginine & $3.70 \pm 0.08^{\mathrm{a}}$ & $3.42 \pm 0.04^{\mathrm{a}}$ \\
Alanine & $2.34 \pm 0.04^{\mathrm{a}}$ & $2.15 \pm 0.01^{\mathrm{a}}$ \\
Tyrosine & $1.86 \pm 0.01^{\mathrm{a}}$ & $1.70 \pm 0.03^{\mathrm{a}}$ \\
Methionine & $0.58 \pm 0.05^{\mathrm{a}}$ & $0.61 \pm 0.04^{\mathrm{a}}$ \\
Valine & $2.66 \pm 0.01^{\mathrm{b}}$ & $2.48 \pm 0.01^{\mathrm{a}}$ \\
Phenylalanine & $2.89 \pm 0.06^{\mathrm{a}}$ & $2.75 \pm 0.02^{\mathrm{a}}$ \\
Isoleucine & $2.66 \pm 0.03^{\mathrm{a}}$ & $2.50 \pm 0.00^{\mathrm{a}}$ \\
Leucine & $4.21 \pm 0.07^{\mathrm{b}}$ & $3.94 \pm 0.06^{\mathrm{a}}$ \\
Lysine & $2.60 \pm 0.58^{\mathrm{a}}$ & $3.39 \pm 0.08^{\mathrm{a}}$ \\
\hline *Different superscripts in the same row means statistically \\
\multicolumn{2}{c}{ different $(\mathrm{p}<0.05)$}
\end{tabular}

Table 3. Antioxidant analysis of tempe flours

\begin{tabular}{|c|c|c|}
\hline \multirow[b]{2}{*}{$\begin{array}{l}\text { Parameter } \\
\text { (per } 100 \text { g db) }\end{array}$} & \multicolumn{2}{|c|}{ Tempe flour from } \\
\hline & $\begin{array}{l}\text { Nongerminated } \\
\text { soybean }\end{array}$ & $\begin{array}{l}\text { Germinated } \\
\text { soybean }\end{array}$ \\
\hline $\begin{array}{l}\text { Antioxidant capacity } \\
\text { (mg AEAC) }\end{array}$ & $186.819 \pm 17.34^{a}$ & $249.79 \pm 5.06^{b}$ \\
\hline Daidzein (mg) & $53.56 \pm 1.02^{\mathrm{b}}$ & $35.96 \pm 3.59^{a}$ \\
\hline Genistein (mg) & $62.46 \pm 0.56^{\mathrm{b}}$ & $44.16 \pm 5.26^{a}$ \\
\hline Total isoflavones (mg) & $116.02 \pm 1.58^{b}$ & $80.13 \pm 8.86^{a}$ \\
\hline Total phenols (mg) & $426.74 \pm 58.88^{a}$ & $483.92 \pm 37.60^{a}$ \\
\hline Vitamin $\mathrm{E}(\mathrm{mg})^{* *}$ & 4.75 & 4.87 \\
\hline
\end{tabular}

digestibility of germinated soybeans (Márton et al. 2010). The moisture content tends to increased after germination. Soybean absorb water during the germination process for its metabolism. Increased water absorption occurs due to the increasing number of cells to becoming hydrated seed. So that

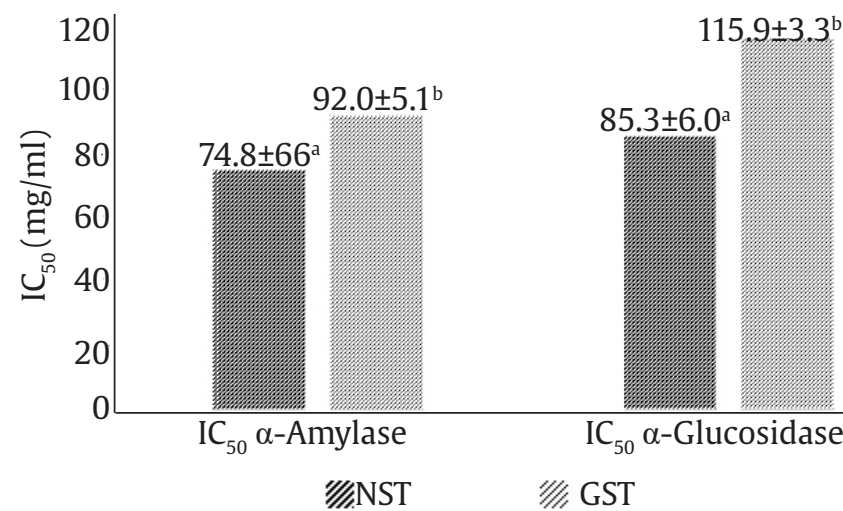

Figure $1 . \mathrm{IC}_{50}$ value of $\alpha$-amylase and $\alpha$-glucosidase in tempe flours. NST=nongerminated soybean tempe flour; GST=germinated soybean tempe flour. Different superscripts means statistically different in each enzyme $(p<0.05)$

there were increased in the moisture content in tempe flour (Warle et al. 2015).

Germination tends to decrease ash content since the soaking and cleaning process leaches the mineral content to the water. The soaking process decreases Mg and Zn content (Márton et al. 2010). Ash content tends to decrease represents mineral loss during germination and washing, but some essential mineral such as $\mathrm{Ca}$ and $\mathrm{Cu}$ could rise during germination (Jiang et al. 2013). However, a study conducted by Astawan and Hazmi (2016) showed that the germination process can increase the ash content of soybean flour. The difference in results may be due to the calcium oxide solution added during the germination process in that study.

Carbohydrate and fat are hydrolyzed to provide the energy needed to synthesize protein (Shi et al. 2010). Decrease fat level is due to the use of fat deposits as an energy during the germination process. Decrease fat levels are also followed by a decrease in carbohydrate. Carbohydrate molecules will be broken down during the germination process to provide nitrogen absorption for the formation of amino acids (Joshi and Kanika 2016).

The increase in protein content may be caused by protein synthesis and reduction of other components from the leaching during boiling or they were used by the tempe mold for its growth (Astawan et al. 1994). Protein synthesis occurs during imbibition to produce enzymes, hormones, and other components needed for radicle growth. Despite the fact that throughout the germination process protein is broken down into amino acids, it seems that the protein synthesis exceeded the protein breakdown. 
The crude fiber content was increased in tempe flour from germinated soybean (GST). In germinated soybean, the amount of crude fiber was contributed by the presence of seed layer, like epidermis, hypodermis, and parenchyma that content fibers such as cellulose, pectin, galactomannan, and glycoprotein (Krisnawati and Adie 2008). Some studies have shown that intake of fibers especially water soluble fiber can also help to control glucose level. Fibers are able to absorb water and bind glucose, thereby reducing glucose availability. Insufficient dietary fiber also resulted in increased digestibility of carbohydrates (Santoso 2011).

Villegas et al. (2008) studied the relationship between soy consumption and the risk of type 2 diabetes mellitus in Chinese women aged 40-70 years. That study showed a higher consumption of soy decreased the occurrence of diabetes. The protective effect of soy was likely due to fiber, protein, polyphenols, and the low glycemic index of soy. It is suggested that the protective effect was not caused by a single component, but was due to the interaction of several components (Sugano 2006).

Soy protein inhibits body fat accumulation through the inhibition of insulin secretion, inhibition of lipogenesis, and enhancement of insulin sensitivity. These mechanisms are affected by the amino acid profile and isoflavones bound to the proteins. In experimental rats given soy protein, there was an increase in insulin sensitivity (Noriega-López et al. 2007). Reduction of body fat accumulation decreases the obesity risk which is one of the risk factors for diabetes mellitus.

Another study showed that soy protein and germinated soy protein were able to stimulate insulin secretion in diabetic rats. Germinated soy protein contains free amino acids which can stimulate insulin secretion better than nongerminated soy protein. Several amino acids show a stronger insulinotropic effect, such as arginine, leucine, and phenylalanine (van Loon et al. 2003). However, the germination process in this research did not increase the content of insulin-stimulating amino acids (Table 2). A decrease in leucine content was observed instead. The availability of amino acids is not necessarily a reference, but the bioavailability affects the effectiveness of the use of these insulinotropic amino acids.

The mechanism of several amino acids in stimulating insulin release are varied. The results of the study using alanine amino acid showed that the addition of $10 \mathrm{mmol} / \mathrm{l}$ alanine in basal glucose concentrations increased insulin secretion three times in cells $\beta$-BRIN-BD11 and 1.6 times on islet. Leucine amino acid stimulate the release of insulin in the cells of $\beta$ pancreas through a process that includes increased mitochondrial metabolism through the activation of $\mathrm{GDH}$, increased production of ATP through leucine transaminases into $\alpha$-toxicity and subsequently enter the TCA cycle through acetyl CoA (Newsholmes et al. 2005).

Arginine affecting the wound healing, cause arginine as the one of the nitric oxide-forming materials (NO) that would help the collagen synthesis in the wound area. Another studies showed that NO will regulate the metabolism of glucose, fatty acids and amino acids, so that the consumption of arginine would decrease fat mass in the obese and diabetic rats. Nitric oxide also enhances glucose transport, lowers glucose, glycogen synthesis, stimulates release of insulin and inhibit the rate of pancreatic $\beta$-cell damage (Utari et al. 2011).

Studies about the amino acid profile in germinated and nongerminated soybeans demonstrated different results. Pomeranz et al. (1977) only found a little difference in amino acid composition between commercial soybean flour and germinated soybean flour. Different results were observed by Mostafa and Rahma (1987) where soybean germination relatively increased the essential and non-essential amino acid content. The highest increase was observed in leucine, tyrosine, phenylalanine, and glutamic acid, while methionine content decreased slightly. The different results obtained might be due to different germination conditions, different soybean varieties used, and different analysis methods.

The fermentation process also affected the amino acid profile of tempe flour. According to the study by Gibbs et al. (2004), fermentation of tempe for 24 hours decreased the content of aspartic acid, glutamic acid, lysine, tyrosine, and serine, while glycine, isoleucine, leucine, proline, and threonine increased. Some amino acids, for example, alanine, valine, arginine, histidine, phenylalanine, cysteine, methionine, and tryptophan tended not to change in content. This is affected by the peptidase activity of $R$. oligosporus.

Germination caused increase production of bioactive compounds with potent antioxidant properties. Studies demonstrated that germination can alter the level of bioactive compounds of soybean by 
increasing lunasin, isoflavone and saponins. Analysed soybeans after $48 \mathrm{~h}$ of germination, concluding that germination reduced tannins while increased total phenolics (Vernaza et al. 2012). The phenolics content of legumes tends to have a positive correlation with its antioxidant capacity. This current study showed that the increase in antioxidant capacity in GST was likely not due to the increase in phenolics as the phenolics content remained constant and the isoflavones decreased. Nevertheless, non-phenolics compounds, including ascorbic acid, tocopherols, phytic acid, carotenoids, and saponins, could also contribute to the antioxidant activity (Lee et al. 2011). The increase in antioxidant capacity may be affected by the increase in protein content in GST. Soy protein has been shown to potentially act as an antioxidant. Antioxidant amino acids and vitamin E work in synergy as antioxidants in the body.

Park et al. (2008) stated that several peptides and amino acids act as antioxidants in soy hydrolysates. The peptide with the highest antioxidant properties was found to have a low molecular weight $(<3 \mathrm{kDa})$ and was mostly comprised of hydrophobic amino acids such as phenylalanine, alanine, and proline. Phenylalanine was the main component found and was believed to be the main active component. When exposed to hydroxyl radicals, phenylalanine is converted into tyrosine which has radical scavenging activity (Park et al. 2008). In Table 2, both tempe flours were observed to have no significantly different phenylalanine and tyrosine content ( $p>0.05)$. Proline, one of the abundant amino acids found in antioxidant peptides, was not analyzed here; therefore, the proline content was not known.

Yuan et al. (2009) has been reported that germination changed the distribution profile of isoflavone. The results showed that after germination, the glycoside contents decreased and the total aglycone content increased. In line with Shi et al. (2010) that malonyl genistin and malonyl daidzin are decreased, but daidzin, genistin, daidzen, and genistein are increased during germination. Zhu et al. (2005) studied the effect of germination on the isoflavone profile of two different soybean varieties, Hutcheson and Caviness. After soaking, the total isoflavone content of both varieties increased to the maximum amount (Hutcheson 2,491 mg/g db and Caviness 2,780 $\mathrm{mg} / \mathrm{g} \mathrm{db}$ ). After this stage, a decrease in the isoflavone content was observed. Another possible cause for the decrease in the isoflavone content may be contributed to the conversion of isoflavones to other flavonoids.

Isoflavone conversion may happen not only during germination but also during fermentation. Soybean flour fermented with Aspergillus oryzae underwent a decrease of total isoflavones after 48 hours of fermentation. Various reactions such as hydroxylation, methylation, glycosylation, and acetylation can occur and change the structure of isoflavones (da Silva et al. 2011). Isoflavone structure is important in determining its antioxidant activity. The antioxidant activity of flavonoids is determined by the arrangement of the functional group bound to the structure such as the hydroxyl group, methyl, double bound, and carbohydrate moieties, and also the degree of polymerization (Heim et al. 2002).

Genistein was the most abundant isoflavone found in both tempe flours. Products high in aglycone isoflavones have higher efficiency in preventing chronic diseases because of their higher absorbability. El-Kordy and Alshahrani (2015) studied the effect of genistein on streptozotocin-induced diabetic rats. Administration of $20 \mathrm{mg} / \mathrm{kg} /$ day of genistein showed a protective effect on pancreatic $\beta$-cells against ROS.

The $\alpha$-amylase and $\alpha$-glucosidase is an enzyme that plays an important role in converting carbohydrates into glucose. Soybean flour known can significantly inhibits the work of enzymes by reducing the increase of postprandial blood glucose (Subramanian et al. 2008). The anti-diabetic actions of the plant is suggested by inhibiting $\alpha$-amylase and $\alpha$-glucosidase which could decrease postpandrial blood glucose level, and also by repairing the damage of pancreatic beta cells, thus enhancing the insulin secretion directly (Febrinda et al. 2014). In this study, no improvement of inhibition activity on starch digestion enzymes was observed due to soy germination. In addition, a decrease in $\alpha$-amylase inhibition (increase in $\mathrm{IC}_{50}$ value) was detected in GST. GST was expected to have lower glycosides due to its phenolics degradation during the germination process. Free phenolics were shown to have lower inhibition activity on $\alpha$-amylase compared to their bound forms (Ademiluyi and Oboh 2013). Bound phenolics which exist mostly in glycosides are hydrophilic and since the enzymes work in an aqueous phase, the direct enzyme-inhibitor interaction is expected to be higher in NST. Compared to the study by Ademiluyi and Oboh (2013), the $\alpha$-amylase and $\alpha$-glucosidase inhibition of soybeans was higher than both tempe flours. This result may be likely because the tempe flours underwent various heating process. 
Heating process decreases the enzyme inhibition property of soy (Gętek et al. 2014).

GST and NST were found to have several different compositions; therefore, they were expected to have different antidiabetic properties. With higher a protein content and antioxidant capacity, GST was expected to have a higher potential in increasing insulin sensitivity in a high-fat diet and in preventing pancreatic $\beta$-cell destruction. NST had a higher leucine content, hence it was expected to increase insulin secretion in a high blood glucose condition. In addition, NST might be more promising in inhibiting starch digestion since it had a higher $\alpha$-amylase and $\alpha$-glucosidase inhibition values (lower IC $\mathrm{C}_{50}$ values than GST). Further study to obtain the optimum germination conditions is needed to increase the bioactive content in germinated soybean tempe.

\section{Conflict of Interest}

The authors have no conflict of interest regarding the results of this research.

\section{Acknowledgements}

The authors would like to thank the Directorate of Research and Community Service, the Directorate General for Research and Development, Ministry of Research, Technology and Higher Education, Republic of Indonesia, through "Penelitian Berbasis Kompetensi 2019" scheme under the name of Made Astawan.

\section{References}

[ADA] American Diabetes Association. 2010. Diagnostic and classification of diabetes mellitus. Diabetes Care 33: 562-569. DOI:10.2337/dc10-S062

Adefegha SA, Oboh G. 2016. Antioxidant and inhibitory of Clerodendrum volubile leaf extracts on key enzymes relevant to non-insulin dependent diabetes mellitus and hypertension. J TU Sci 10:521-533. DOI:10.1016/j. jtusci.2015.10.008

Ademiluyi AO, Oboh G. 2013. Soybean phenolic-rich extract inhibits key-enzymes linked to type 2 diabetes ( $\alpha$-amylase and $\alpha$-glucosidase) and hypertension (angiotensin I converting enzyme) in vitro.J Exp Toxicol Pathol 65:305-309. DOI:10.1016/j.etp.2011.09.005

[AOAC] Association of Official Analytical Chemist. 2012. Official Method of Analysis of the Association of Official Analysis Chemist. Gaithersburg: AOAC.

Astawan Met al. 1994. Changes in protein-nutritional quality of Indonesian dried-salted fish after storage. Journal of the Science of Food and Agriculture 66:155-161.

Astawan M et al. 2015. Pengaruh konsumsi tempe kedelai Grobogan terhadap profil serum, hematologi, dan antioksidan tikus. J Teknol dan Industri Pangan
26:155-162. DOI:10.6066/jtip.2015.26.2.155

Astawan M, Hazmi K. 2016. Karakteristik fisikokimia tepung kecambah kedelai. I Pangan 25:105-112.

Astawan M et al. 2016a. Karakteristik fisikokimia tepung tempe kecambah kedelai. J Gizi Pangan 11:35-42.

Astawan M et al. 2016b. Application of vacuum packaging to extend the shelf life of fresh-seasoned tempe. Int Food Res J 23:2571-2580.

Astawan M et al. 2017. Tempe: Sumber Zat Gizi dan Komponn Bioaktif untuk Kesehatan. Bogor: IPB Press.

da Silva LH et al. 2011. Effect of the fermentation of whole soybean flour on the conversion of isoflavones from glycosides to aglycones. Food Chem 128:640-644. DOI:10.1016/j.foodchem.2011.03.079

El-Kordy EA, Alshahrani AM. 2015. Effect of genistein, a natural soy isoflavone, on pancreatic $\beta$-cells of streptozotocin-induced diabetic rats: Histological and immunohistochemical study. JMAU 3:108-119. DOI:10.1016/j.jmau.2015.03.005

Febrinda AE et al. 2014. Hyperglycemic control and diabetes complication preventive activities of Bawang Dayak (Eleutherine palmifolia L. Merr.) bulbs extracts in alloxan-diabetic rats. International Food Research Journal 21:1405-1411.

Firdaus M et al. 2010. Prevention of endothelial dysfunction in streptozotocin-induced diabetic rats by Sargassum echinocarpum extract. Medical Journal of Indonesia 19:33-35

Gętek M et al. 2014. The active role of leguminous plant components in type 2 diabetes. I Evid Based Complementary Altern Med 1-12. DOI:10.1155/2014/293961

Gibbs BF et al. 2004. Production and characterization of bioactive peptides from soy hydrolysate and soy-fermented food. Int Food Res J 37:123-131. DOI:10.1016/j.foodres.2003.09.010

Heim KE et al. 2002. Flavonoid antioxidants: chemistry, metabolism, and structure-activity relationships. J Nutr Biochem 13:572-584. DOI:10.1016/S09552863(02)00208-5

Hung PV, Nhi NNY. 2012. Nutritional composition and antioxidant of several edible mushrooms grown in Southern Vietnam. Int Food Res J 19:611-615.

Jiang $S$ et al. 2013. Food quality improvement of soy milk made from short-time germinated soybeans. Foods 2:198-212. DOI:10.3390/foods2020198

Joshi P, Kanika V. 2016. Effect of germination and dehulling on the nutritive value of soybean. Nutrition and Food Science 46:595-603. DOI:10.1108/NFS-10-2015-0123

Kadar AD et al. 2018. Gas chromatography coupled with mass spectrometry-based metabolomics for the classification of tempe from different regions and production processes in Indonesia. J Biosci Bioeng 126:411-416. DOI:10.1016/j.jbiosc.2018.03.020

Kanetro B, Astuti S. 2013. Profile of amino acid for stimulation of insulin secretion in the extract after protein removal of local legumes sprout. AGRITECH 33:258-264.

Koh SP et al. 2012. Nutritive value between fermented and germinated soybean: $\gamma$-aminobutiric acid, amino acids content, and antioxidant properties. Borneo Science 31:143-151.

Krisnawati A, Adie MM. 2008. Varieties morphology of seeds from some soybean germplasm genotypes. Germplasm Bulletin 14:14-18.

Lee $\mathrm{JH}$ et al. 2011. Comparative analyses of total phenols, flavonoids, saponins, and antioxidant activity in yellow soybeans and mung beans. Int J Food Sci Technol 
46:2513-2519. DOI:10.1111/j.1365-2621.2011.02775.x

Márton M et al. 2010. The role of sprouts in human nutrition: A review. Acta Univ Sapientiae Almentaria 3:81-117.

Mostafa MM, Rahma EH. 1987. Chemical and nutritional changes in soybean during germination.J Food Chem $23: 257-272$.

Newsholmes P et al. 2005. New insights into amino acid metabolism, $\beta$-cell function and diabetes. Clinical Science 108:185-194.

Noriega-López L et al. (2007). Pancreatic insulin secretion in rats fed a soy protein high fat diet depends on the interaction between the amino acid pattern and isoflavones. J Biol Chem 282:20657-20666. DOI:10.1074/jbc.M701045200

Park SY et al. 2008. Purification and characterization of antioxidant peptides from soy protein hydrolysate. $J$ Food Biochem 34:120-132. DOI:10.1111/j.17454514.2009.00313.X

Pomeranz Y et al. 1977. Flour from germinated soybean in high protein bread. J Food Sci 42:824-827. DOI:10.1111/j.1365-2621.1977.tb12613.x

Puteri NE et al. 2018. Characterization of biochemical and functional properties of water-soluble tempe flour. Journal of Food Science and Technology 38:147-153. DOI:10.1590/fst.13017

Sancheti S et al. 2009. Chaenomeles sinensis: a potent $\alpha$ and $\beta$ - glucosidase inhibitor. Am J Pharm and Toxicol 4:8-11. DOI:10.3844/ajptsp.2009.8.11

Santoso A. 2011. Food fibre and health benefits. Magistra 75:35-40.

Setter SM et al. 2006. Diabetes. In: Helms RA, Quan DI, Herfindal ET, Gourley DR (Eds.). Textbook of Therapeutics: Drug and Disease Management. Philadelphia: Lippincott Wiliams and Wilkins. pp. 1042-1075

Shahidi F et al. 2012. Antioxidants and human health. In: Yu L, Tsao R, Shahidi F (Eds.). Cereals and Pulses: Nutraceutical Properties and Health Benefits. Oxford: J Wiley. pp. 273-308.

Shi $\mathrm{H}$ et al. 2010. Comprehensive profiling of isoflavones, phytosterols, tocopherols, minerals, crude protein, lipid, and sugar during soybean (Glycine max) germination. I Agric Food Chem 58:4970-4976. DOI:10.1021/jf100335j

Subramanian $\mathrm{R}$ et al. 2008. In vitro $\alpha$-glucosidase and $\alpha$-amylase enzyme inhibitory effects of Andrographis paniculata extract and andrographolide. Acta
Biochimia Polonica 55:391-398.

Sugano M. 2006. Nutritional implications of soy. In: Sugano M (Eds.). Soy in Health and Disease Preventing. Boca Raton: CRC Pr. pp. 1-16.

Sumi H, Yatagai C 2006. Fermented soybean components and disease prevention. In: Sugano M (Eds.). Soy in Health and Disease Preventing. Boca Raton: CRC Pr. pp. 251-278.

Thalapaneni NR et al. 2008. Inhibition of carbohydrate digestive enzymes by Talinum portulacifolium (Forssk) leaf extract. J Complement Integr Med 5:110. DOI:10.2202/1553-3840.1120

Utari D et al. 2011. Potency of amino acid in tempeh for improving lipid profile and diabetes mellitus. Journal of National Public Health 5:166-170.

Van Loon LJC et al. 2003. Amino acid ingestion strongly enhances insulin secretion in patients with longterm type 2 diabetes. Diabetes Care 26:625-630. DOI:10.2337/diacare.26.3.625

Vernaza MG et al. 2012. Antioxidant and anti-inflammatory properties of germinated and hydrolysed Brazilian soybean flours. Food Chemistry 134:2217-2225. DOI:10.1016/j.foodchem.2012.04.037

Villegas R et al. 2008. Legume and soy food intake and the incidence of type 2 diabetes in the Shanghai Women's Health Study. Am J Clin Nutr 87:162-167.

Warle BM et al. 2015. Effect of germination on nutritional quality of soybean (Glycine max). OSR-JESTFT 9:13-16. DOI:10.9790/2402-09421316

Xu BJ, Chang SKC. 2007. A comparative study on phenolic profiles and antioxidant activities of legume as affected by extraction solvents. J Food Sci 72:159-166. DOI:10.1111/j.1750-3841.2006.00260.x

Yuan JP et al. 2009. Changes of isoflavone profile in the hypocotyls and cotyledons of soybeans during dry heating and germination.J Agric Food Chem 57: $9002-$ 9010. DOI:10.1021/jf902248b

Zhu D et al. 2005. Isoflavone contents in germinated soybean seeds. Plant Food Human Nutr J 60:147-151. DOI:10.1007/s11130-005-6931-0 